\title{
Nineteenth-century, non-existent buildings of the Castle Hill in Lublin
}

\author{
Krzysztof Janus \\ https://orcid.org/0000-0002-5391-3140 \\ k.janus@pollub.pl
}

Department of Architecture, Urban and Spatial Planning,

Faculty of Civil Engineering and Architecture, Lublin University of Technology

\begin{abstract}
This article presents the history of no longer existing $20^{\text {th }}$ century buildings against the background of the turbulent history of the Castle Hill in Lublin. It shows the location, appearance and functions of the buildings, which were supposed to serve administrative, residential and technical purposes and some of them became a place of slaughter and executions. The analysis was based on data from archive searches as well as from geo-radar studies.
\end{abstract}

Key words: Castle Hill in Lublin, Administration House, Prison in Lublin Castle, geo-radar research

\section{Introduction}

The oldest history of settlement on the castle hill dates back to the $6^{\text {th }}$ century AD. In the $8^{\text {th }}$ century the first town was most likely built. These data were obtained thanks to archaeological research carried out in various periods. Despite the good historical and archaeological recognition of the castle hill, the place still hides a lot of secrets and unresolved issues, thanks to which various, sometimes even fantastic, theories are being developed. The location on the hill and the shaping of the immediate surroundings was almost ideal for the location of the defensive point. Over the years, this function has been maintained but transformed and the buildings have evolved. In the $13^{\text {th }}$ century the brick tower, which still exists today, was probably built, and in the $14^{\text {th }}$ century Casimir the Great greatly expanded and transformed the building into a brick, defensive royal castle. From that moment on, as the royal seat, the buildings were repeatedly transformed, changed and renovated according to their rank. In the $18^{\text {th }}$ century, due to, among other things, the geopolitical situation, the castle fell into disrepair and at its end it became a source of building material for town houses or road fortification ${ }^{1}$. The facility looked like a 'scarecrow' and there was no idea of how to develop it until the central authorities decided to build a prison on a hill that would cover almost the entire area. The concept of building the castle was carried out by J. Stomf and later supervised by J. Hempel ${ }^{2}$. During this period, documentation was created to illustrate the condition designed against the background of the ruins, which is extremely useful to illustrate the location and course of the royal walls. Fortunately, the construction project assumed the preservation of the castle chapel building and the tower - the jungle.

The prison facilities were built in stages until 1824, partly using the medieval walls as foundations and as a source of building material ${ }^{3}$. Buildings during the prison period often underwent changes (especially the interiors). Until the end of the nineteenth century, the prison was housed within the structure of the walls of the quadrilateral foundation designed by Stompf, but these areas proved to be insufficient. At the beginning of the twentieth century, the expansion of small technical buildings began in the area of the hill, which was lim- 
ited on the one hand by the existing prison facility and on the other hand by the slope and buildings located at the foot of the hill. Hence the only possible form of expansion was the courtyard area and small areas between the edge of the slope and the wall of the main building. Over the next few years, buildings were built in the courtyard and on the northern and eastern sides.

Due to the nature of the building, the building regulations that were in force in the city did not include the prison area. On the one hand, archives in the army have always been more "tidy", but on the other hand, they were actually unavailable. As it turned out, during the search, most of the archives of the facility were in various collections not related to the military, the problem was their fragmentation and incomplete preservation.

\section{Administrative house building}

It was not possible to establish the exact date when it was created, but it most probably took place around 1905. At that time, a massive three-storey building was constructed right in front of the prison facade, almost completely covering the western side of the facade. Admittedly, a document from 1905 was found in which the Governor's Engineer E. Sidorski presented the "Project for the construction of a police detention centre in the city of Lublin, $2^{\text {nd }}$ Administrative House", may be the project of the building in question, but it differs significantly from the one known from archival photographs (Fig. 1, Fig. 2, Fig. 3). The project includes a drawing of the elevation, cross-section, basement projection, ground floor and storey ${ }^{4}$ but does not include a situation plan or the number of the plot on which it was to be built ${ }^{5}$. The projections describe in detail the individual functions, which mainly indicate that the facility was to include staff housing, laundry and cellars. The project has been dimensioned in the fathoms for unspecified reasons. At that time, it was very often the case that the designed building differed significantly from the one constructed sometimes by changing the number of windows in the facade and sometimes by adding additional storeys. In this case, the building had to be quadrupled and gained one more storey. It is very doubtful whether this project can be attributed to the building constructed on the plot in question ${ }^{6}$, but no other building could have been identified that could have served as an administration building under arrest in Lublin at the time. The architecture of the facade is quite characteristic for the beginning of the $20^{\text {th }}$ century, except for the window in the middle axis of the first floor (Fig. 3), which seems to refer to the windows of the neo-Gothic castle. It may be a project of an unrealised building completely unrelated to the castle hill, but if we assume that it concerns the building in question, significant changes have been made during its construction. It is possible that the building was simply meant to be as large as possible and its outline was created during the construction of the foundations in such a way that it could be safely erected right at the edge of the slope.

In any case, the building was built around 1905, in place of the square in front of the main entrance. The entrance gate to the medieval castle and the royal chambers were located in this place. The location of this building forced at least partial removal of the remains of the foundations of the royal castle and if the cellars underneath were built, the older foundations were probably demolished and could have been used as a reused building material. A big problem with the execution was the difficult ground conditions. Half of the building was located on the inner side of the medieval castle (i.e. on the ground close to stable) and half on the slope (where thick layers of secondary layers were deposited for years). It is not known how the contractors approached it, but it seems highly probable that serious problems with heterogeneous settlement of the walls may have occurred during the operation of the building ${ }^{7}$.

5 It was not until 1918 that the Potocki Palace (Old Penitentiary) passed from the army to the police.

6 Based on the Tariff of Houses of the City of Lublin and its suburbs:Piaski, Czwartek and Kalinowszczyzna from 1904, the only buildings that can be linked to the function of the project were located at 9 Zamkowa Street (488) - a prison and 3 Poczętkowska Street (349) Police Board.

7 Due to the nature of the facility, the Lublin City Construction Inspectorate had no access to the site and any technical problems were only the responsibility of the prison authorities. 

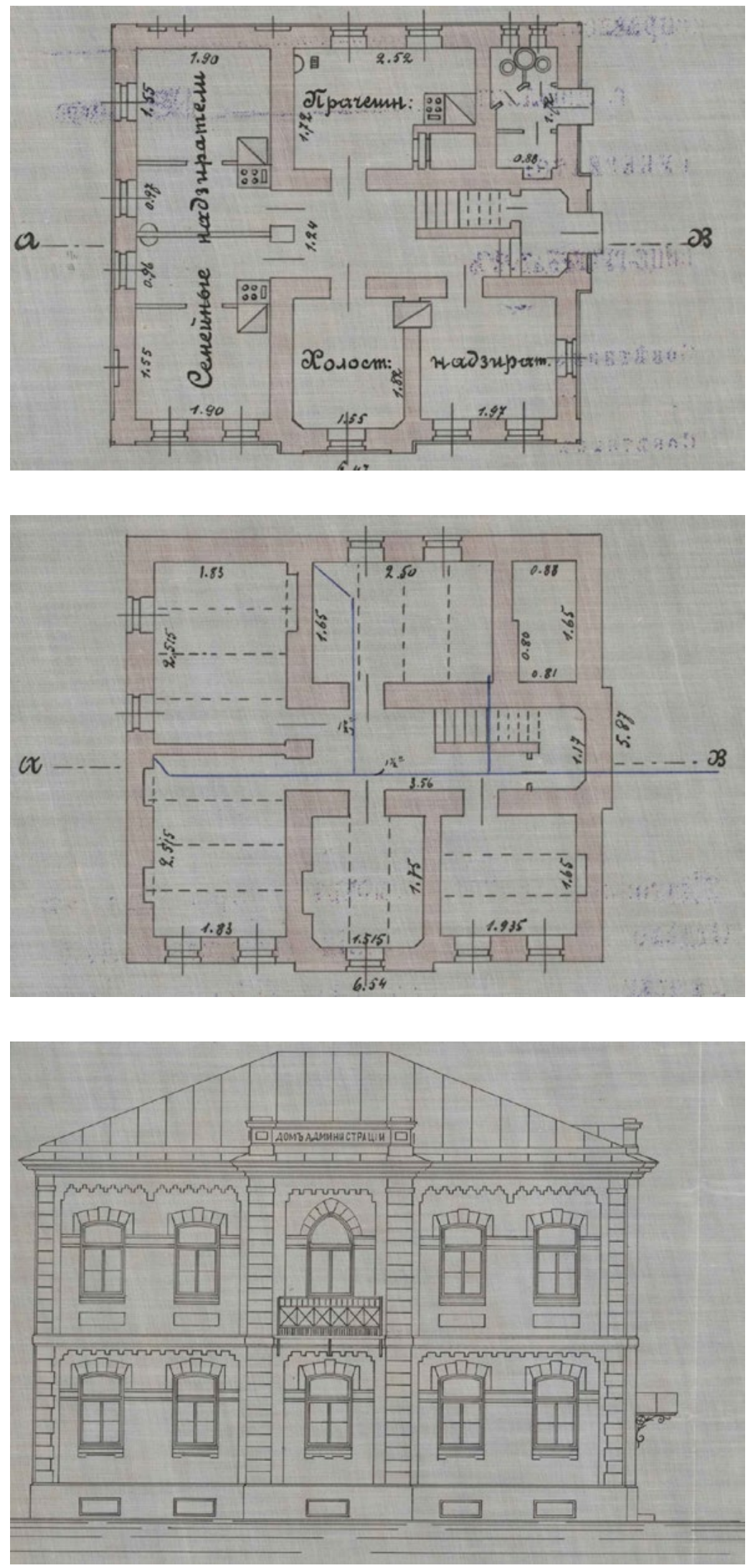

Fig. 1. Ground floor plan - Project for the construction of a police detention centre in the city of Lublin, 2. Dom Administracyjny, E. Sidorski. 1905, APL, PmL. ref. 172

Fig. 2. Basement plan - Project for the construction of a police detention centre in the city of Lublin, 2. Administrative House, E. Sidorski. 1905, APL, PmL. ref. 172

Fig. 3. Façade - Project for the construction of a police detention centre in the city of Lublin, 2. Administrative House, E. Sidorski. 1905, APL, PmL. Ref. 172. 
The first technical documentation we managed to find comes from 1918 and shows the exact layout of the three floors (ground floor, first and second floor - Fig. 4, Fig. 5, Fig. 6), without cellars ${ }^{8}$. It was made by the Austrian military, dimensioned in metres. The drawings show exactly the layout of the rooms, equipment or dimensions, do not describe their functions. However, it can be assumed that the building contained both flats and office spaces.
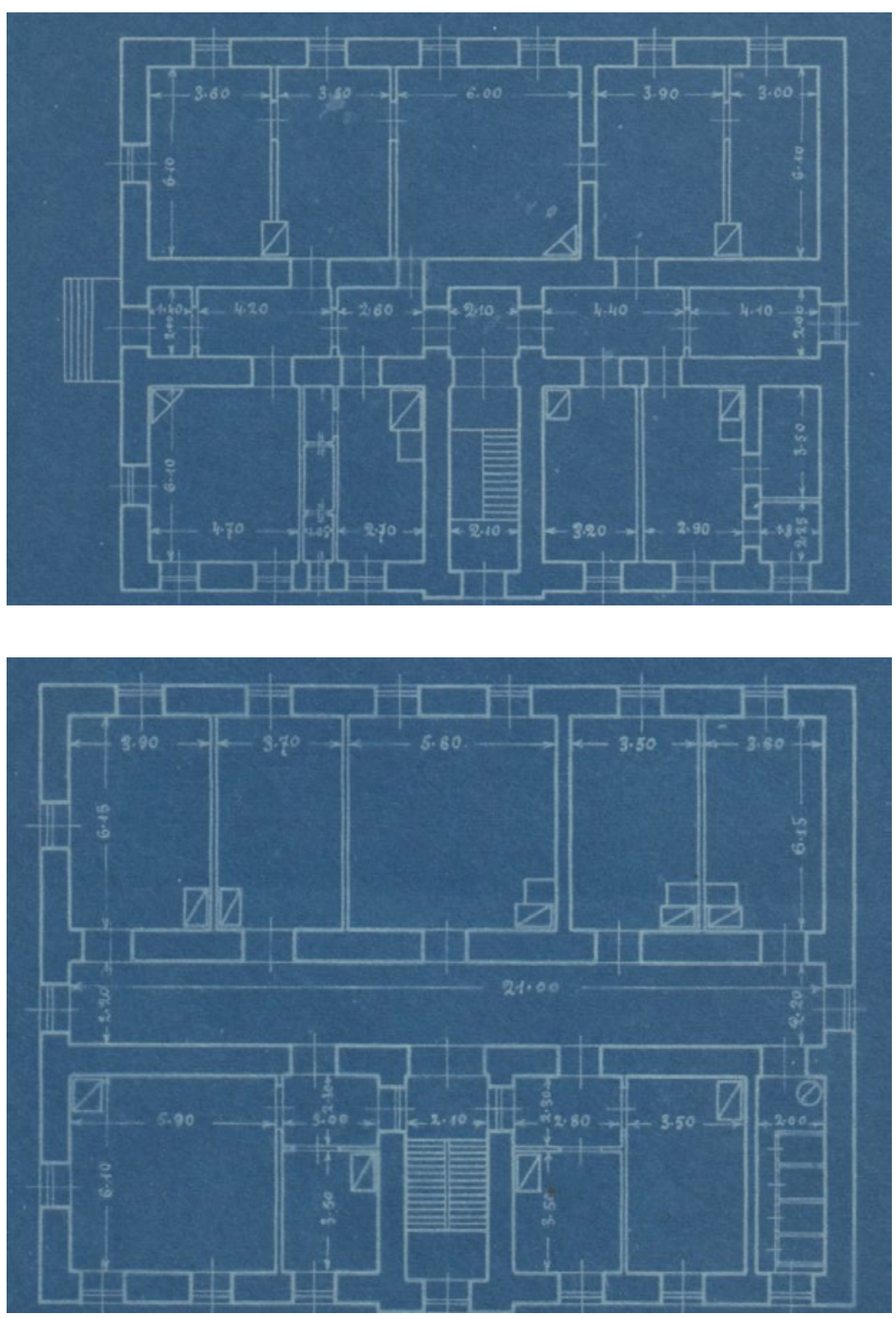

Fig. 4. Ground floor plan of the administrative building, 1918, APL, C. and K. District Headquarters in Lublin. sign. 411, p. 8
Fig. 5. $1^{\text {st }}$ floor plan of the administrative building, 1918, APL, C. and K. District Headquarters in Lublin. sign. 411, p. 8 


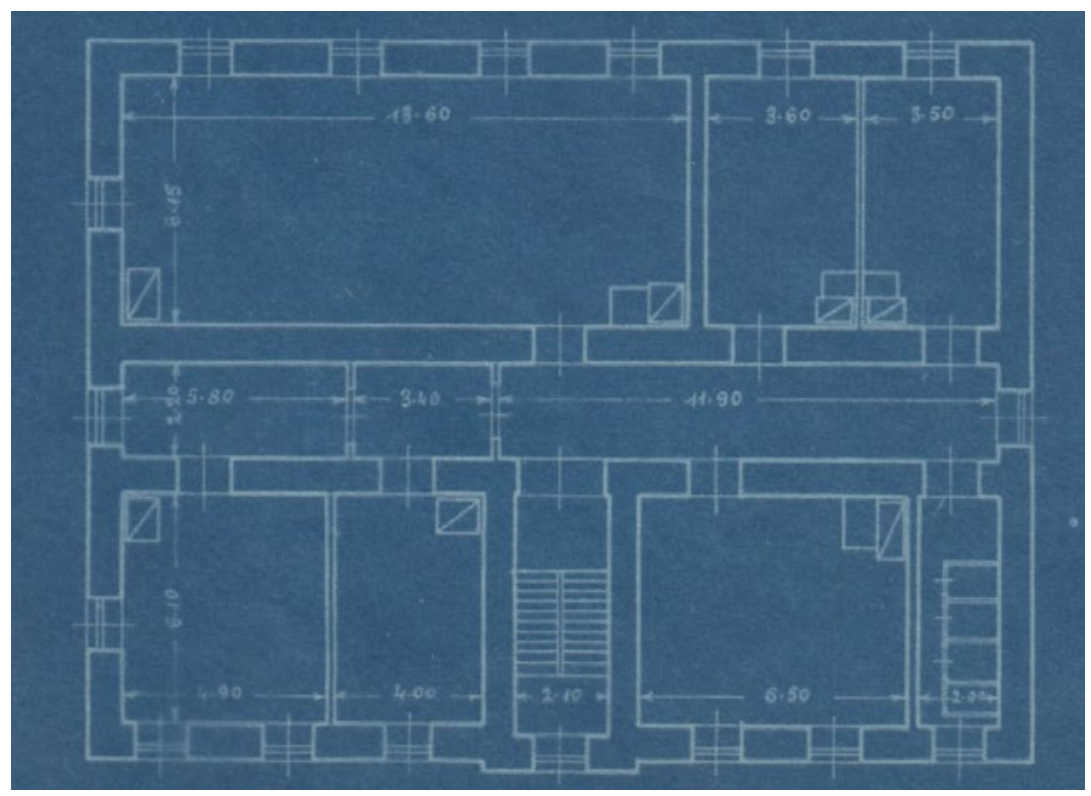

Fig. 6. $2^{\text {nd }}$ floor plan of the administrative building, 1918, APL, C. and K. District Headquarters in Lublin. sign. 411, p. 8

The further fate of the facility is not known except that it was used by the Germans during the German occupation, and in 1944 - 54 prisoners were executed in the cellars. The administrative building was probably demolished $^{9}$ around 1954, when the square in front of the castle and the current layout of the slope for the $10^{\text {th }}$ anniversary of the PKWN (Polish National Liberation Association) were formed. At that time, the prison was liquidated and the buildings were handed over to the Voivodeship House of Culture. Since then, apart from repairs to the surface and current repairs, no major changes have taken place in the area.

The determination of the location of the administrative building itself was quite simple due to the available maps and archival photographs. Although there is uncertainty about the accuracy of the archives, it should not be more than one metre. Archival documents do not specify the location of basements or their size, but we do know that they existed. During the period of the building's construction, it was common in Lublin to make cellar ceilings and staircases in sectional form on steel beams (cement mortar was used quite often). There is a certain probability (although very low) that during the demolition of the building the basement ceilings were not removed ${ }^{10}$, which was not confirmed by geo-radar surveys. It could be that during the demolition process the ceilings were preserved but the cellars were buried, which was also not confirmed by the geo-radar. This leads to the conclusion that the only reliable source for confirming the location of the building and its degree of preservation is archaeological excavation.

The geo-radar research defined quite precisely the outline of the administrative building, but only in the scope of the east wing (additionally, most of it was located in the inaccessible space of the flower bed). Anomaly A3 (Fig. 13) probably marks the partially buried (but not precisely) basements of the east wing, while it does not show any other unbasement parts ${ }^{11}$. From here it can be assumed that the stairs from the east led to the basement. In the central part there was a corridor throughout the whole length of the building and the rooms were located on the eastern side. The remaining part did not have cellars or the cellars were completely demolished. An attempt to reconstruct the storey is shown in Fig. 15. 


\section{Other buildings - currently nonexistent}

The bathhouse building was located in the courtyard. In fact, apart from the drawing and photographs of the roof, nothing is known about it.

On the northern side, there were still a few small farm buildings, which show maps from the interwar period.

Historical photographs show that the greenery in the prison area seemed to be taken in an orderly form (on the slope there were terraces, at the entrance of the flower beds and the layout of alleys). The order and maintenance was probably done by the prisoners.

All these facilities and the fence were probably dismantled (like the administrative building) around 1954 after the end of the prison and the introduction of cultural functions on the hill.

\section{Conclusions}

Over the years of its existence, the castle hill has undergone many changes in its form and function. Since the oldest history, there have been defensive points, a castle, a royal seat, a defensive castle, a prison, a place of execution and a cultural unit. These periods were intertwined with stormy events connected with the fall and destruction, whether caused by war turmoil or lack of repairs.

The administrative building, against the background of the history of the castle hill, has functioned here for a relatively short time, only 50 years. However, due to the site of the massacre that lasted for 10 years in its cellars, it has become part of a shameful history that should be remembered and documented.

\section{References}

[1] Janus K., Kocki W., Przesmycka N., Geo-radar research "Plots 41, in front of the Lublin Castle building", Lublin 2018.

[2] Tomicka W., Lublin Castle in the $19^{\text {th }}$ century, Monuments Protection, 1954, pp. 189-196.

[3] Wojciechowski, S. Renaissance Lublin Castle, Monuments Protection, 1954, 178-182.

[4] State Archive in Lublin, Plans of the City of Lublin, no. 172.

[5] State Archive in Lublin, Plans of the City of Lublin, ref. 178.

[6] State Archives in Lublin, C. and K. Poviat Headquarters in Lublin, ref. 411.

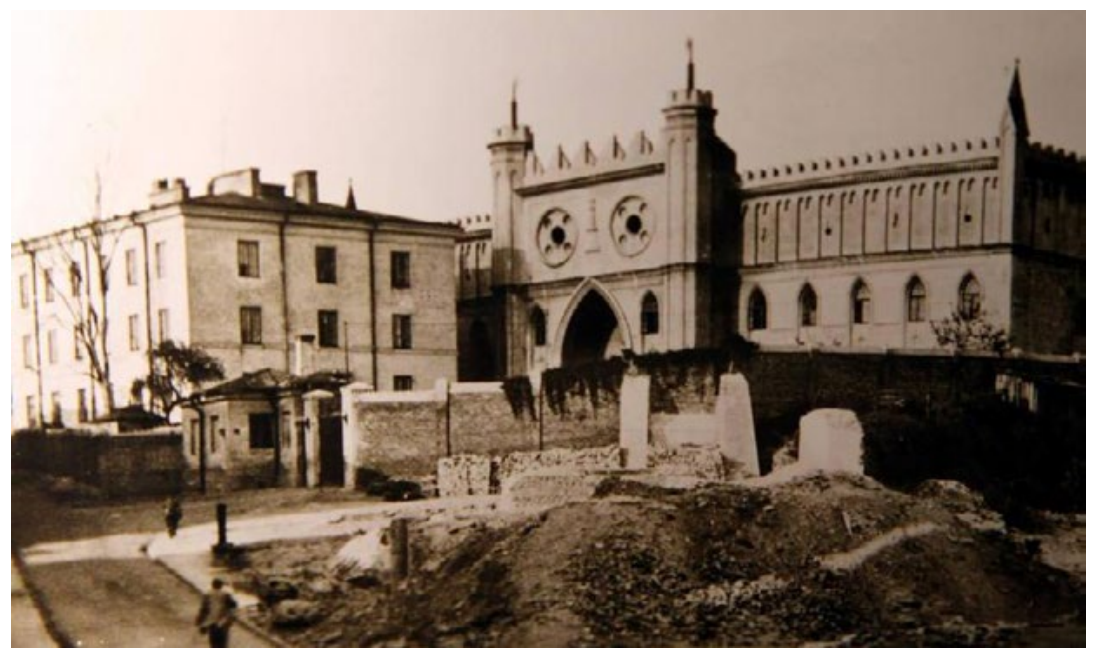

Fig. 7. Administration building, museumlubelskie.pl, access 2019 

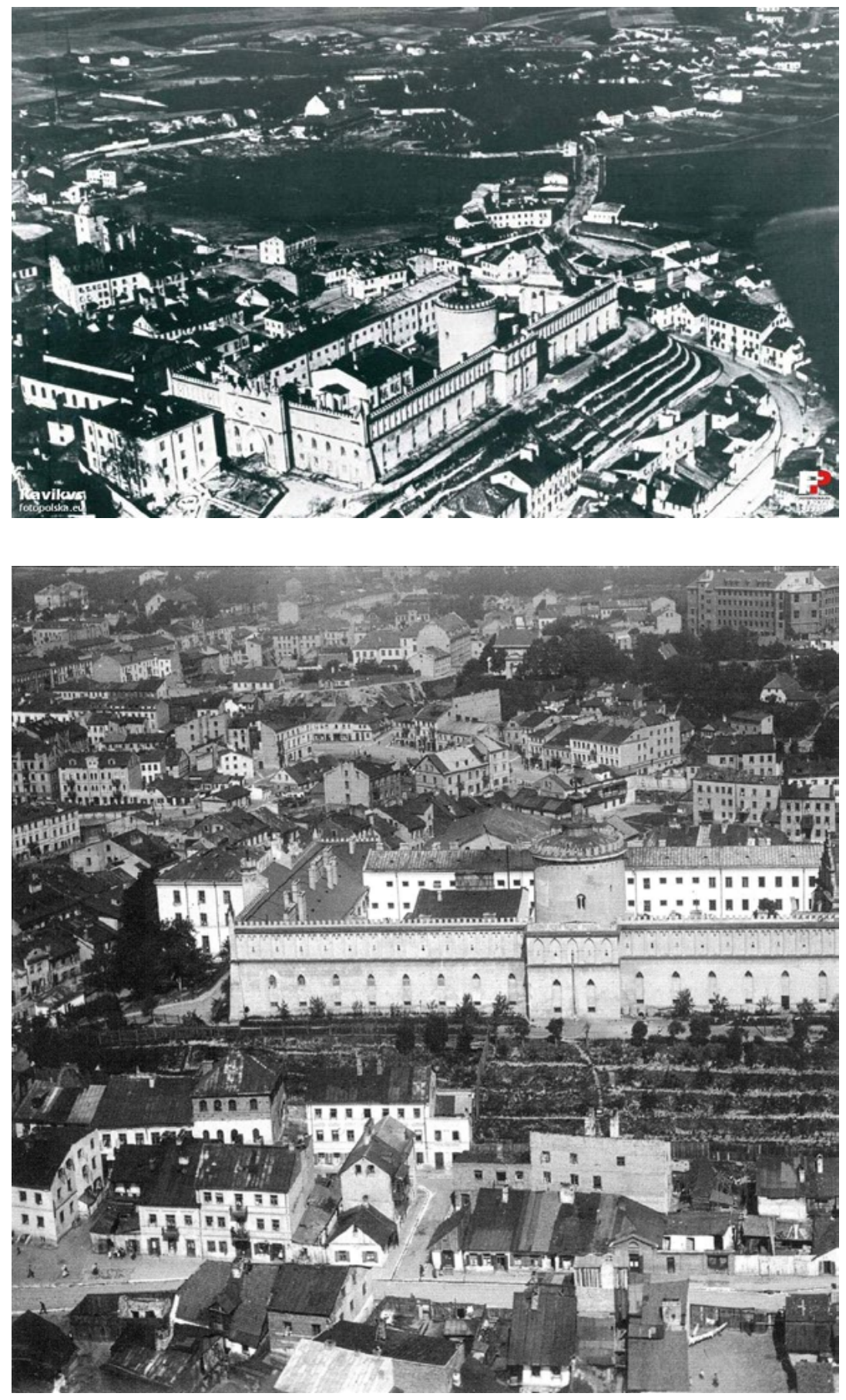

Fig. 8. aerial photography - red arrow marks administration building, green arrow marks bathhouse building
Fig. 9. Aerial photography 1938. - Red arrow marks the administration building, green arrow marks the bathhouse, https://fotopolska. eu/Lublin/b58146,Panoramy_Lublina, 24,48.html?f=633676-foto accessed 20.10.2020 r. 

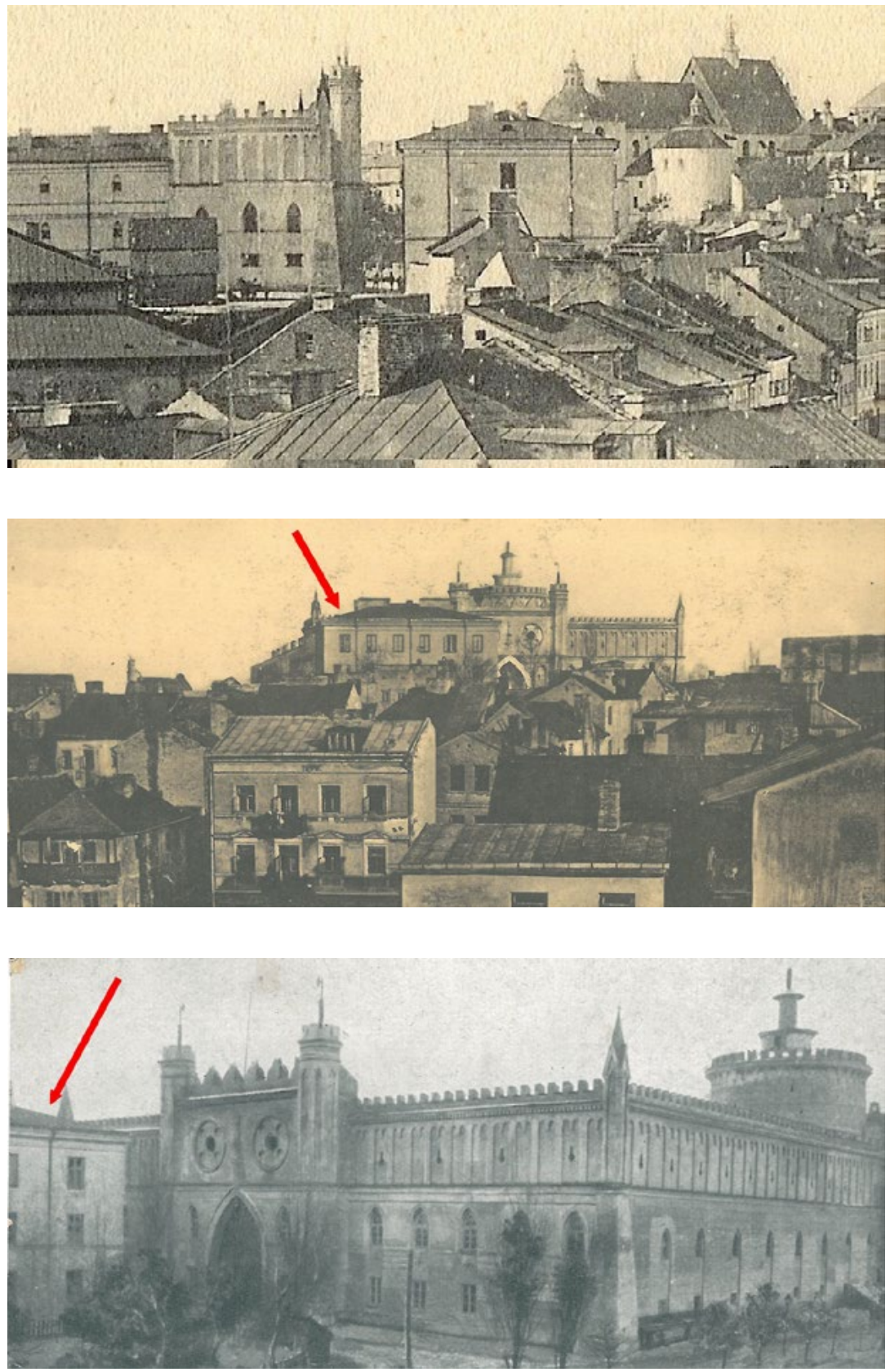

Fig. 10. Fragment of a postcard depicting the discussed object from the north - in the author's possession

Fig. 11. A fragment of the postcard "Lublin - Castle" - with a red arrow marks the administrative building, owned by the author

Fig. 12. Postcard depicting the castle hill - the red arrow marks the administrative building, owned by the author 

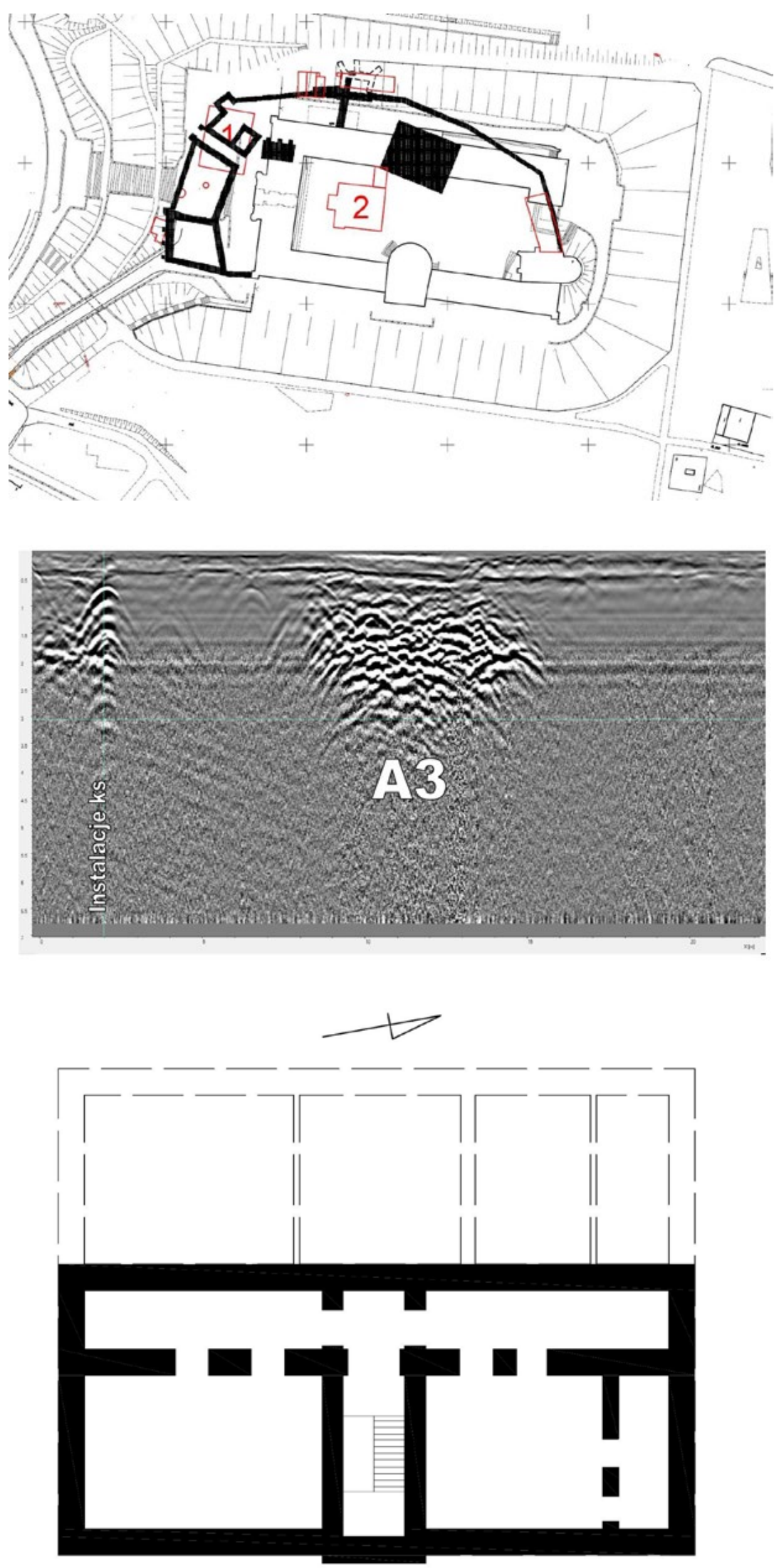

Fig. 13. Location of non-existing buildings on the castle hill (red buildings of the $20^{\text {th }}$ century, black defensive walls and buildings of the royal castle), Fig. K. Janus

Fig. 14. section W.53 showing a fragment of the inaccurately buried basement of the eastern wing of the administration building Geo-radar research "Plot of land 41 , in front of the Lublin Castle building", K. Janus, W. Kocki, N. Przesmycka, Lublin 2018, p. 107.

Fig. 15. Attempted reconstruction of the basement plan of an administrative building from 1918, Fig. K. Janus 